\title{
Opposisjon i posisjon
}

\author{
Hun er best kjent som utfordrer av «the establishment». Nå er lona Heath nyvalgt president \\ for det britiske Royal College of General Practitioners og stiller snart til gjenvalg som \\ styremedlem i verdensorganisasjonen for allmennleger. Hva har skjedd?
}

Iona Heath og mannen David skal etter planen være hjemkommet fra en av sine mange reiser i de skandinaviske utkanter sent kvelden før. Selv er jeg i starten av mitt første opphold utover turistformatet i hennes London. Jeg har fulgt kartet som den alltid hjelpsomme David har sendt meg på e-post, og fryser slik nordmenn gjør her - optimistisk tynnkledd i det bedragersk grønne vinterlandskapet. Plutselig kikker Iona Heath opp på meg fra en dør en halv etasje under og litt bortenfor den jeg har ringt på. Jeg ledes rett inn i og gjennom det som viser seg å være Davids arbeidsværelse. Her arbeides det, for å si det slik. Huset ligger i det som definitivt må kalles et pent strøk - «north of the river» er det viktigste kriteriet i denne byen - men er ellers påfallende lite pompøst.

Hjemmet er preget av en familie som har bodd lenge og aktivt sammen og har en felles lidenskap for bøker, fotografering og musikk. Og toleranse for pågående prosjekter. Her bor Iona Heath, nyvalgt president $i$ the Royal College of General Practitioners (RCGP), hennes pensjonerte arkitektmann, som leder The Society for the Protection of Ancient Buildings, og fire dager i uken to små barnebarn som David er dagpappa for. Vern av fortid, nåtid og fremtid.

«Välkommen til Londons bästa vandrarhem» står det på skiltet i gangen.

\section{Cum scientia caritas}

«Science with Compassion» er mottoet for det britiske selskapet for allmennmedisin. RCGP ble stiftet i 1952, fire år etter opprettelsen av the National Health Service (NHS). Storbritannia hadde allerede da et listepasientsystem for dem som hadde råd til å registrere seg hos en lege. Denne var ansvarlig for å «provide primary and personal medical care for every patient registered with them». Med opprettelsen av NHS kom retten til fastlege for alle. Samtidig ble det innført henvisningsplikt fra allmennlege til offentlige spesialisthelsetjenester. Det er interessant å lese beskrivelsene av hvordan britiske allmennleger nesten segnet under sitt utvidede mandat, faglig og kapasitetsmessig, samtidig som utfordringene ledet til konsolidering av profesjonen. Opprettelsen av RCGP beskrives som «an outstanding event in the history of British medicine» (1). I dag har selskapet 38000 medlemmer, det vil i praksis si nesten alle praktiserende allmennleger i Storbritannia. Tidligere var medlemskap valgfritt, men fra og med 2008 må nye allmennleger gjennomgå et kvalifiseringsprogram og sertifiseres av RCGP før de kan praktisere på egen hånd.

Da Iona Heath i 2009 ble valgt til president for RCGP for de neste tre årene var det nok en del som stusset. Hun har drevet klinisk allmennpraksis i de samme lokalene i en såkalt belastet bydel i London i 35 sammenhengende år, hun har aldri tatt en doktorgrad eller navigert strategisk i maktens korridorer. Likevel er hun trolig en av dem som har hatt størst innflytelse innenfor sitt eget fagområde, langt utover Storbritannias grenser. Skandinavia og Norge spiller en viktig rolle i den historien.

\section{At dører skal opna seg}

- Jeg var en vanlig, hardt arbeidende allmennlege som delte døgnet mellom pasientene mine i Kentish Town og omsorgen for to små barn. Men i 1989 kom RCGP med et forslag som ville fått store negative konsekvenser for de yngste kollegene. Poenget var at jeg ble forbannet på dem som satt med makten i selskapet og deres arroganse overfor ungdommen. På det tidspunktet skulle RCGP velge nytt styre (council). Jeg fant ut at alle som meldte sitt kandidatur hadde rett til et «50 word statement», en slags valgtale, som ville bli distribuert til samtlige medlemmer. Da stilte jeg til valg, uten tanke på at jeg faktisk kunne bli valgt, rett og slett for å få mitt opprørte budskap spredt.

- Men du ble valgt.

- Ja, og med flest stemmer av alle. Da tenkte jeg at jeg må jo ha truffet et eller annet. Jeg ble plassert i forskningskomiteen i RCGP. De tenkte antakelig at jeg kunne gjøre minst skade der.

- For du hadde og har fortsatt aldri forsket?

- Nei. Jeg er formidler, ikke forsker. Men uansett ble jeg i kraft av vervet i forskningskomiteen sendt til en allmennmedisinsk kongress i København tidlig i 1990-årene. Der hørte jeg blant andre Carl Edvard Rudebeck og Kirsti Malterud. De sto for en filosofisk tilnærming til medisinen som jeg ikke var vant med. Det åpnet for gjenkjennelse ut fra min egen erfaring og for et faglig fellesskap.

- Med andre ord - et lykkelig møte?

- Nei, nei. Det ble ikke noe møte. Jeg våget ikke snakke til dem engang. Men det markerte uansett starten på et langvarig og nært forhold til nordisk allmennmedisin, etter hvert også til mange og gode venner i de tre skandinaviske landene. I 1994 dro jeg alene, uten å kjenne noen, til en utdanningskonferanse på Soria Moria i Oslo. Det første som skjedde, var at vi ble tatt med til Astrup Fearnley-museet og fikk en flott presentasjon av utstillingen. Dessuten sang dere ved middagene og danset etterpå. Jeg var overveldet over rikdommen i referanser og vitaliteten i miljøet.

Her går intervjuerens tanker andre veien, til 1995 og fornemmelsen av faglig åpenbaring og gjenkjennelse over et essay, The mystery of general practice, skrevet av en for meg ukjent engelsk kollega ved navn Iona Heath (2). Ingenting er som gjengjeldt kjærlighet.

- Nå snakker du både litt norsk og litt svensk?

- Jeg forstår noe. Svenske Tomas Tranströmer er en poet jeg er glad i. Jeg liker å se dikt på originalspråket selv når jeg ikke forstår ordene. Språk opptar meg, språklig mangfold ikke minst.

Iona Heath bidro senest i fjor på Nordisk kongress i allmennmedisin med et - for noen overraskende - innlegg i en opphetet debatt om nordisk versus engelsk i sammenhenger der kolleger fra de nordiske land møtes. Hun oppfordret til å verne om nordisk fagspråk og årvåkenhet i forhold til en tiltakende anglifisering. Mangfold og meningsdybde er essensielle kvaliteter ved selve medisinfaget.

\section{A fortunate woman}

Intervjuet finner sted samme dag som Iona Heath skal på avslutningsmiddag med praksiskollegene sine. Over det lille bordet vi sitter ved i dagligstuen vaier en hjerteformet, litt sliten ballong med påskriften «Happy Retirement!». Hun har hatt sin siste dag på kontoret.

- Er det trist? 


\section{Iona Caroline Heath}

Født 1950 i Kent, England

- MB BChir, University of Cambridge, 1974

- Selvstendig allmennpraksis Caversham Group Practice, Kentish Town, London 1977-2010

- Utnevnt til Commander of the Order of the British Empire i 2000

- Leder av the British Medical Journal's Ethics Committee, 2004-09

- WONCA World Executive fra 2007

- President i the Royal College of General Practitioners fra 2009

Foto David Heath

- Ja og nei. Jeg vil savne pasientene. Men jeg tror det er riktig å trekke seg tilbake fra praksis før man må, for å si det slik. Det er krevende å holde seg oppdatert og skarp nok, og jeg har sett altfor mange eldre kolleger gjemme seg bak ritualene. Det er et helvetes ansvar - «a hell of a responsibility» - å være allmennlege. Å slippe å ta alle de daglige beslutningene som får så potensielt store konsekvenser for folk, er som å legge fra seg en byrde.

Så kommer ett av mange øyeblikk $\mathrm{i}$ intervjuet da jeg kjenner på essensen av engelsk dannelse og evnen til å uttrykke seg bitende presist og høflig om ubehagelige temaer. - You should be careful not to outstay your welcome.

Jeg er glad hun snakker om seg selv ... - Du valgte i sin tid Caversham og Kentish Town. Det var ikke selvsagt, gitt din bakgrunn i typisk engelsk middelklasse. Hvorfor?

- Kentish Town har historisk sett vært preget av hvite arbeidere med lav inntekt, mange med irsk bakgrunn. Immigranter fra resten av verden er kommet i bølger senere og utgjør en stor andel av innbyggerne i dag. Jeg begynte der i praksis som turnuslege (trainee) 25 år gammel, med en klar bevissthet om den urettferdige fordelingen av makt og velstand i samfunnet. Jeg tror jeg alltid har hatt et radikalt instinkt. Dessuten var jeg naturligvis et produkt av en universitetsutdanning som startet i 1968.

- Bar selve praksisen preg av å være radikal?

- Det kan du trygt si. Mange av våre pasienter på den tiden var gamle stalinister som fortsatt bar sine jakkemerker med stolthet. To påfølgende administrative ledere for kontoret vårt var gift med hver sin generalsekretær for det britiske kommunistpartiet. Og venterommet vårt hadde røde setetrekk. Nabopraksisen over gangen hadde blå. I mange år var vi ambassadeleger for henholdsvis Kina og Vietnam.
Kina avviklet vi på eget initativ etter Tiananmen-massakren.

- Hva er dine refleksjoner nå ved avslutningen av livet som lege i praksis?

- Det slår meg hvor tett man veves sammen med pasientene sine over tid. Vi har vokst sammen, og det kliniske hovedfokuset har umerkelig endret seg gjennom ulike livsfaser. Først er man ung mor med barn, så middelaldrende i tidsklemme og nå snart gammel. Det er typisk at de siste sinte innleggene jeg har skrevet til $B M J$ har handlet om hvor dårlig vi behandler de gamle. Jeg synes det er en skam hvordan man under dekke av ikke å diskriminere både underbehandler, feilbehandler og overbehandler. Medisin er skreddersøm, ikke konfeksjon.

\section{Makt med brodd}

Hun er en populær foredragsholder og kjent for sine litterære referanser og poengterte illustrasjoner. En britisk kollega jeg snakket med, sa at hun får vanlige allmennleger til å føle seg verdifulle. Det kan de saktens trenge. NHS knaker i sammenføyningene, og allmennlegene får kjeft fra alle kanter.

- Ja, for meg var det den viktigste grunnen til å stille som president for RCGP. Det er viktig for legene, men enda viktigere for pasientene og for samfunnet som helhet at legene i førstelinjen har faglig selvtillit. Sønnen vår har forresten laget en parodi på foredragene mine. Han sier: «I could do this. You just stand up and you say: Here are some very interesting quotations from the books I have read. General practice is a wonderful thing. Thank you very much.» - Og den andre grunnen?

- Jeg vil at RCGP skal bidra til at britiske allmennleger - britiske leger for den del slutter å være seg selv nok, «become less insular». Det er en tendens i dette landet til å tro at de eneste vi eventuelt kan lære noe som helst fra er andre engelsktalende land, uansett hvor frastøtende deres helsesystemer er.
- Er det grunnen til at du lot deg velge inn i ledelsen i allmennlegenes verdensorganisasjon WONCA?

- For å være ærlig er min eneste ambisjon der å få slutt på gubbeveldet. Ingen bør sitte i en slik posisjon i mer enn to perioder, og det kan du trygt si at en del av de eldre herrene i WONCA har gjort.

Iona Heath ytrer seg fortløpende. En kortfattet tematisk oversikt ser omtrent slik ut: helse og ulikhet, forebygging, etikk, fattigdom, medikalisering og tillit. For tiden er hun opptatt av nobelprisvinner Amartya Sens siste bok The idea of justice.

- Jeg identifiserer meg med det han skriver om at vi kaster bort for mye tid og krefter på å opprette rettferdige institusjoner fremfor å bekjempe eksisterende urettferdighet.

- Men kan du fortsette med dine frilynte skriverier fra posisjonen som president for RCGP?

- Noen i selskapet så nok helst at jeg sluttet å skrive. Men jeg skiller mellom rollene og er nøye med å skrive under som privatperson når jeg har sterke meninger. Det tenker jeg å fortsette med.

- Innleggene mine i $B M J$ utløser regelmessig opprørte reaksjoner i form av «rapid responses». Det er særlig en amerikansk «management consultant» som har lagt meg for hat. Så lenge jeg hører fra ham, vet jeg at jeg er på rett spor.

\section{Elisabeth Swensen}

elswense@online.no

Tidsskriftet

\section{Litteratur}

1. Tait I. History of the College. www.rcgp.org.uk/ services/history_heritage_archives/ history_chronology/history_essay.aspx (23.2.2010).

2. Heath I. The mystery of general practice. London: The Nuffield Trust, 1995. 